\title{
ANALISIS ELASTISITAS PERMINTAAN KONSUMEN TERHADAP PRODUK DAN HARGA KERIPIK PADA UKM DI KECAMATAN BATURAJA TIMUR OGAN KOMERING ULU
}

\author{
Styawan Arta ${ }^{1}$, Munajat ${ }^{2}$, dan Henny Rosmawati ${ }^{3}$ \\ 1 Alumni Program Studi Agribisnis Fakultas Pertanian Universitas Baturaja \\ 2,3. Dosen Prodi Agribisnis Fakultas Pertanian Universitas Baturaja
}

\begin{abstract}
This study aims to calculate the elasticity of consumer demand for changes in the price of SME chips in East Baturaja District, and calculate the elasticity of consumer demand for chips products in East Baturaja District. The study was conducted from March to May 2017 in 3 (three) small and medium enterprises. The research method used is survey method. Sampling method / sample using non probability sampling. The results show the demand for price changes for Rempeyek and banana chips on the changed prices is in elastic or (Ed <1) and the type of sweet potato chips to the changing price are elastic. demand for other products all types of chips have substitution properties similar to those seen in the above explanation are all positive substitutes but the difference is only the percentage of cross elasticity, or has the property $(E q>0)$.
\end{abstract}

Key words : Elasticity, Small and medium enterprises, Consumer Demand, Product, and Price.

\section{A. PENDAhuluan}

Usaha kecil dan menengah (UKM), memegang peranan yang sangat besar dalam memajukan perekonomian di Indonesia. Selain sebagai salah satu alternatif lapangan kerja baru, UKM juga berperan mendorong laju pertumbuhan ekonomi pasca krisis moneter tahun 1997 disaat perusahaan-perusahaan besar mengalami kesulitan dalam mengembangkan usahanya. UKM merupakan salah satu bentuk usaha kecil masyarakat yang berdirinya bersifat inisiatif seseorang dan memanfaatkan berbagai sumber daya alam yang berpontensial di suatu daerah yang belum diolah secara komersial. Industri kecil dan industri kerajinan rumah tangga di Indonesia mempuyai nilai strategis, salah satu industri kecil dan industri rumah tangga adalah industri makanan dan minuman. Jenis industri makanan dan minuman di Indonesia merupakan jumlah industri terbanyak. Pada tahun 2005 jumlah industri kecil dan kerajinan rumah tangga ada 857.496 unit. (Andri, 2013)

Provinsi Sumatra Selatan khususnya di Kabupaten Ogan Komering Ulu memiliki 20 jenis usaha kecil dan menengah UKM terdiri dari 125 pelaku usaha kecil dan menengah, yang diantaranya usaha keripik. Keripik salah satu usaha yang paling banyak di usahakan di Kabupaten Ogan Komering Ulu.

Di Kabupaten Ogan Komering ulu memiliki 12 kecamatan di antaranya adalah kecamatan Baturaja Timur, di mana kecamatan Baturaja Timur merupakan salah satu kecamatan pemasok keripik terbanyak di kabupaten Ogan Komering Ulu (Disperindag, 2014).

Di Kecamatan Baturaja Timur terdapat 8 pelaku usaha yang bersifat formal, di antaranya UKM keripik yang kapasitas produksi paling banyak yaitu UKM "Cita Rasa" keripik peyek sebanyak $300 \mathrm{Kg} / \mathrm{bln}$, UKM "Arta" keripik pisang sebanyak $800 \mathrm{Kg} /$ th dan UKM "Harmoni" keripik ubi sebanyak $167 \mathrm{Kg} /$ th. Usaha kecil dan menengah yang berlokasi di kecamatan Baturaja Timur kabupaten Ogan Komering Ulu. Produk keripik industri rumah tangga ini potensi marketnya besar. Selama ini, banyak sekali produk keripik itu kurang digarap dengan serius, sehingga terjadi fluktuasi permintaan dan berdampak pada pendapatan pelaku usaha itu sendiri, Fluktuasi permintaan adalah ketidak tetapan atau guncangan terhadap permintaan suatu produk barang dan sebagainya, atas segala hal. Oleh karna itu maka menarik dilakukan penelitian tentang "Analisis Permintaan Konsumen Terhadap Produk dan Harga Keripik pada UKM Di Kecamatan Baturaja Timur Kabupaten Ogan Komering Ulu”.

Berdasarkan informasi di atas maka yang menjadi rumusan masalah yang akan dikaji pada penelitian ini adalah untuk menganalisis elastisitas permintaan konsumen terhadap perubahan harga keripik serta untuk menganalisis elastisitas permintaan konsumen terhadap produk keripik UKM di Kecamatan Baturaja Timur? 


\section{B. METODOLOGI PENELITIAN}

Penelitian ini dilaksanakan pada usaha kecil dan menengah keripik di Kecamatan Baturaja Timur Kabupaten Ogan Komering Ulu pemilihan lokasi di lakukan dengan sengaja (purpoive sampling) dengan pertimbangan bahwa lokasi yang di ambil memiliki kriteria yang sesuai dengan penelitian yang akan dilakukan. terdapat 3 (tiga) usaha kecil dan menengah yaitu UKM "Cita Rasa" keripik peyek sebanyak 300 $\mathrm{Kg} / \mathrm{bln}$, UKM "Arta" keripik pisang sebanyak 800 Kg/Th dan UKM "Harmoni" keripik ubi sebanyak 167 $\mathrm{Kg} / \mathrm{Th}$. di tiga UKM tersebut yang paling dominan dalam memasarkan produk di 5 toko besar di baturaja yaitu Toko Asia Mart di samping FIF Baturaja, Toko Citra RSS Holindo, Toko Dea Sukaraya, Toko Saqila depan RS. DKT Baturaja dan Toko Daya Pasar Baru dan waktu peneitian akan dilaksanakan mulai dari bulan Maret sampai dengan Mei 2017.

Metode Penelitian yang digunakan dalam penelitian ini adalah metode survei. Metode penarikan contoh yang digunakan adalah metode tidak acak (non probability sampling) (azwar, 2004). Metode pengumpulan data yang digunakan dalam penelitian ini adalah observasi dan wawancara dengan kuisioner sebagai alat pengumpul data.

Untuk menjawab tujuan penelitian pertama dapat dijelaskan sebagai berikut:

\section{$E_{d}$ \\ Persentasi Perubahan Jumlah Barang Yang Diminta \\ Persentasi Perubahan Harga}

Misalkan harga berubah dari $\mathrm{P}$ menjadi $\mathrm{P}_{1}$ dan jumlah barang yang diminta berubah dari $\mathrm{Q}$ menjadi $\mathrm{Q}_{1}$. Dengan pemisalan ini rumus diatas dapat dinyatakan sebagai berikut :

$$
E_{d}=\frac{\frac{Q_{1}-Q}{Q}}{\frac{P_{1}-P}{P}}
$$

Keterangan :

$\mathrm{E}_{\mathrm{d}}$ : Elastisitas Permintaan

$\mathrm{Q}_{1}$ : Perubahan Permintaan

Q : Permintaan Awal

$\mathrm{P}_{1}$ : Perubahan Harga

$P$ : Harga Awal

Untuk menjawab tujuan penelitian pertama dapat dijelaskan sebagai berikut:

$$
=\frac{\mathrm{E}_{\mathrm{q}}}{\text { Persentasi Perubahan Jumlah Barang XYang Diminta }}
$$

Secara matematis elastisitas silang dapat diformulasikan sebagai berikut :

$$
\mathrm{E}_{\mathrm{q}}=\frac{\frac{\Delta \mathrm{Qx}_{\mathrm{x}}}{\mathrm{Qx}}}{\frac{\Delta \mathrm{P}_{\mathrm{y}}}{\mathrm{P}_{\mathrm{y}}}} \quad \text { Atau } \quad \mathrm{E}_{\mathrm{q}}=\frac{\Delta \mathrm{Q}_{\mathrm{x}}}{\Delta \mathrm{P}_{\mathrm{y}}} \cdot \frac{\mathrm{P}_{\mathrm{y}}}{\mathrm{Q}_{\mathrm{x}}}
$$

Keterangan :

$\mathrm{Q}_{\mathrm{x}}$ : Jumlah barang $\mathrm{X}$ yang diminta konsumen dalam unit waktu tertentu

$\mathrm{P}_{\mathrm{y}}$ : Tingkat harga barang Y per unit dan

$\Delta$ : Perubahan yang relatif kecil

\section{HASIL DAN PEMBAHASAN}

\section{Analisis Elastisitas Permintaan Konsumen Terhadap Harga dan Produk Keripik pada UKM di Kecamatan Baturaja Timur Kabupaten Ogan Komering Ulu.}

\section{a. Harga Keripik dan Permintaan Konsumen}

Dari hasil penelitian selama satu bulan yang saya lakukan menunjukan bahwa jenis keripik yang dijual di lima toko besar di kecamatan baturaja timur diperoleh dari tiga pelaku usaha yaitu UKM "Cita Rasa" keripik peyek, UKM "Arta" keripik pisang dan UKM "Harmoni" keripik ubi. Dengan harga jual yang bervariasi dari Bulan Maret dan Bulan April yang dikarnakan ketidak seimbangan bahan baku yang diperlukan dalam proses produksi oleh karna dampak kenaikan harga Bahan Bakar Minyak (BBM).

Dalam penelitian yang saya lakukan terdapat lima toko yang paling dominan dalam memasarkan produk UKM keripik, dari kelima toko tersebut menjual jenisjenis keripik yaitu keripik peyek, keripik pisang dan keripik ubi. Dimana dengan harga keripik yang berbeda dalam 2 bulan terakhir, dapat dilihat pada Tabel 1 . berikut.

Tabel 1. Data Harga Jual Keripik Bulan Maret dan April 2017

\begin{tabular}{lcc}
\hline Komponen & \multicolumn{2}{c}{ Bulan } \\
\cline { 2 - 3 } & Maret (Rp/Kg) & April (Rp/Kg) \\
\hline Peyek & 50.000 & 60.000 \\
Pisang & 45.000 & 50.000 \\
Ubi & 45.000 & 50.000 \\
\hline Sum
\end{tabular}

Sumber : Analisi Data Primer 2017

Jumlah total permintaan keripik di lima toko yang menjadi sampel pada dua bulan ialah untuk keripik peyek pada bulan maret $377 \mathrm{~kg}$ bulan april $360 \mathrm{~kg}$, keripik pisang pada bulan maret $345 \mathrm{~kg}$ bulan april 317 $\mathrm{kg}$ dan keripik ubi pada bulan maret $339 \mathrm{~kg}$ bulan april $298 \mathrm{~kg}$. Untuk lebih jelas dapat dilihat pada tabel 2 dan Tabel 3. 
Tabel 2. Data Penjualan Keripik Pisang Pada Bulan Maret 2017

\begin{tabular}{lccc}
\hline Distributor & \multicolumn{3}{c}{ Bulan Maret } \\
\cline { 2 - 4 } & $\begin{array}{c}\text { Peyek } \\
\text { (Kg/Bulan) }\end{array}$ & $\begin{array}{c}\text { Pisang } \\
\text { (Kg/Bulan) }\end{array}$ & $\begin{array}{c}\text { Ubi } \\
(\text { Kg/Bulan) }\end{array}$ \\
\hline Asia Mart & 78 & 70 & 68 \\
Citra Rss Holindo & 78 & 70 & 67 \\
Dea Sukaraya & 74 & 68 & 68 \\
Saqila Rs. Dkt & 73 & 69 & 68 \\
Daya Pasar Baru & 74 & 68 & 68 \\
\hline Total & $\mathbf{3 7 7}$ & $\mathbf{3 4 5}$ & $\mathbf{3 3 9}$ \\
\hline
\end{tabular}

Sumber : Analisi Data Primer 2017

Berasarkan Tabel 2 dan Tabel 3, dapat diketahui bahwa penjualan yang paling tinggi pada bulan Maret dan April yakni penjualan peyek

Tabel 3. Data Penjualan Keripik Pisang Pada Bulan April 2017

\begin{tabular}{lccc}
\hline Distributor & \multicolumn{3}{c}{ Bulan April } \\
\cline { 2 - 4 } & $\begin{array}{c}\text { Peyek } \\
\text { (Kg/Bulan) }\end{array}$ & $\begin{array}{c}\text { Pisang } \\
\text { (Kg/Bulan) }\end{array}$ & $\begin{array}{c}\text { Ubi } \\
\text { (Kg/Bulan) }\end{array}$ \\
\hline Asia Mart & 73 & 65 & 58 \\
Citra Rss Holindo & 75 & 65 & 57 \\
Dea Sukaraya & 69 & 60 & 64 \\
Saqila Rs. Dkt & 70 & 63 & 60 \\
Daya Pasar Baru & 73 & 64 & 59 \\
\hline Total & $\mathbf{3 6 0}$ & $\mathbf{3 1 7}$ & $\mathbf{2 9 8}$ \\
\hline
\end{tabular}

Sumber : Analisi Data Primer 2017

\section{b. Nilai Elastisitas Permintaan Terhadap Perubahan Harga}

Perubahan harga tidak mempengaruhi penjualan keripik peyek dan pisang pada lima toko yang ada di Kec. Baturaja Timur, namun keripik ubi terjadi elastisitas penjualan keripik yang berkurang penjualannya dari kenaikan harga jual keripik, untuk lebih jelasnya dapat dilihat pada Tabel 4. berikut:

Tabel 4. Perhitungan Elastisitas Permintaan Keripik Tergahap Harga Yang Berubah Pada Buan Maret dan April 2017

\begin{tabular}{|c|c|c|}
\hline \multirow[t]{2}{*}{ Komponen } & \multicolumn{2}{|c|}{ Bulan } \\
\hline & Maret (Rp/Kg/Bln) & April (Rp/Kg/Bln) \\
\hline $\begin{array}{l}\text { Harga } \\
\text { (Rp/Kg/Bln) }\end{array}$ & & \\
\hline Keripik Rempeyek & 50.000 & 60.000 \\
\hline Keripik Pisang & 45.000 & 50.000 \\
\hline Keripik Ubi & 45.000 & 50.000 \\
\hline
\end{tabular}

\begin{tabular}{lcc}
$\begin{array}{l}\text { Konsumsi } \\
\text { (Kg/Bln) }\end{array}$ & Keripik & \\
Keripik Rempeyek & 377 & 360 \\
Keripik Pisang & 345 & 317 \\
Keripik Ubi & 339 & 298 \\
\hline $\begin{array}{l}\text { Elastisitas } \\
\text { Keripik Rempeyek }\end{array}$ & $-0,22 \%$ & (in elastis) \\
Keripik Pisang & $-0,73 \%$ & (in elastis) \\
Keripik Ubi & $-1,09 \%$ & (elastis) \\
\hline
\end{tabular}

Sumber : Analisi Data Primer 2017

Dari tabel diatas dapat kita lihat elastisitas keripik rempeyek $-0,22 \%$ dan keripik pisang $-0,73 \%$ yang berarti kedua keripik tersebut bersifat in elastis atau $\left(E_{d}<1\right)$ yang artinya setiap perubahan harga mengakibatkan perubahan yang kecil dalam jumlah yang diminta sebelumnya, sedangkan keripik ubi $1,09 \%$ yang artinya elastis atau $\left(E_{d}>1\right)$ setiap perubahan harga mengakibatkan perubahan yang besar dari jumlah yang diminta sebelumnya, dikarenakan keripik ubi hanya mempunyai 1 (satu) macam rasa sehingga selera konsumen kurang terpenuhi di bandingkan dengan jenis keripik rempeyek dan keripik pisang yang mempunyai pilihan rasa.

Elastisitas permintan dapat dijelaskan dalam gerafik yang berbentuk kurva permintaan dimana jumlah awal permintaan $\left(\mathrm{Q}_{-} \mathrm{Q}_{1}\right)$ dan dalam jumlah akhir permintaan masing-masing keripik, harga awal dan harga akhir (P$\mathrm{P}_{1}$ ), yang digambarkan kedalam grafik berbentuk kurva permintaan pada lampiran berikut.

\section{Elastisitas Keripik Rempeyek}

Dari analisis elastisitas keripik Rempeyek yang dihasilkan dapat dijelaskan pada kurva Gambar 1. Di dibawah ini

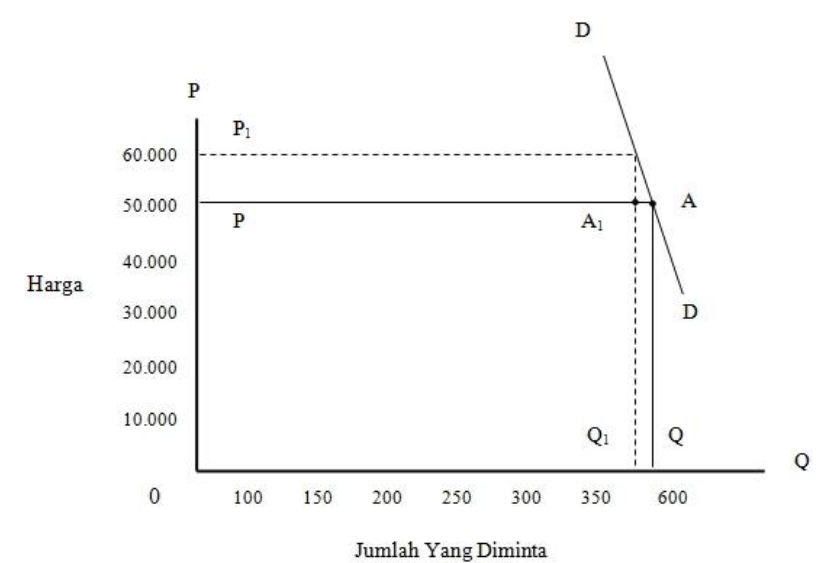

Gambar 1. Jumlah permintaan keripik Rempeyek (Q $\left.\mathrm{Q}_{1}\right)$ dan perubahan harga $\left(\mathrm{P}-\mathrm{P}_{1}\right)$ selama bulan Maret dan bulan April 2017

Dapat dilihat bahwa mula-mula ekuilibirium berada pada titik A pada keadaan keseimbangan tersebut diatas, dengan harga pada bulan Maret adalah Rp.50.000/kg dan jumlah permintaan sebesar $377 \mathrm{~kg}$ karena pada bulan April harga penjualan keripik naik menjadi Rp.60.000/kg atau kenaikan harga sebesar 20\% dengan akibat penurunan jumlah yang diminta sebesar $360 \mathrm{~kg}$ atau jumlah yang diminta sebesar $4 \%$ ketitik $\mathrm{A}_{1}$ berarti elastisitas permintaan atas keripik peyek $E_{d}=-$ $4 / 20=-0,22 \%$. Bersipat in elastis $\left(E_{d}<1\right)$ artinya setiap perubahan harga mengakibatkan perubahan yang kecil dalam jumlah yang diminta sebelumnya. Keripik rempeyek tidak mengalami elastisitas dari perubahan harga dikarnakan mempunyai banyak pilihan rasa dan jenis sehingga walau pun harga naik selera konsumen tetap tidak berkurang. 


\section{Elastisitas Keripik Pisang}

Dari analisis elastisitas keripik pisang yang dihasilkan dapat dijelaskan pada kurva pada Gambar 2. Di dibawah ini yaitu :

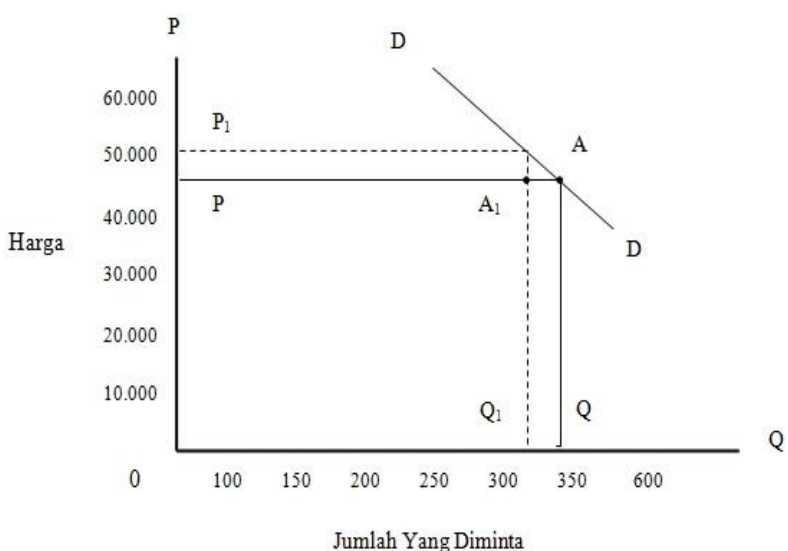

Gambar 2. Jumlah permintaan keripik pisang $\left(\mathrm{Q}-\mathrm{Q}_{1}\right)$ dan perubahan harga $\left(\mathrm{P}-\mathrm{P}_{1}\right)$ selama bulan Maret dan bulan April 2017

Dapat dilihat mula-mula ekuilibirium berada pada titik A pada keadaan keseimbangan tersebut diatas,dengan harga pada bulan Maret adalah Rp.45.000/kg dan jumlah permintaan sebesar $345 \mathrm{~kg}$ karena pada bulan April harga penjualan keripik naik menjadi Rp.50.000/kg atau kenaikan harga sebesar $11 \%$ dengan akibat penurunan jumlah yang diminta sebesar $317 \mathrm{~kg}$ atau jumlah yang diminta sebesar $8 \%$ ketitik $\mathrm{A}_{1}$ berarti elastisitas permintaan atas keripik pisang $E_{d}=8 / 11=0,73 \%$. Dari perhitungan tersebut dapat disimpulkan permintaan keripik pisang ini bersipat in elastis $\left(E_{d}<1\right)$ yang artinya koefisien elastisitas permintaan tersebut adalah diantara nol dan satu. dikarnakan persentasi perubahan harga lebih besar dari pada persentasi perubahan jumlah yang diminta. Keripik pisang tidak mengalami elastisitas penyebabnya hampir sama dengan keripik rempeyek karena memiliki pilihan rasa yaitu rasa original, susu dan coklat. Namun Jenis keripik ini merupakan makanan cemilan walaupun harganya naik dan selera konsumen tetap tetapi konsemen masih mengurangi konsumsinya walaupun tidak terlalu banyak.

\section{Elastisitas Keripik Ubi}

Dari analisis elastisitas keripik ubi yang dihasilkan dapat dijelaskan pada kurva pada Gambar 3. Di dibawah ini yaitu:

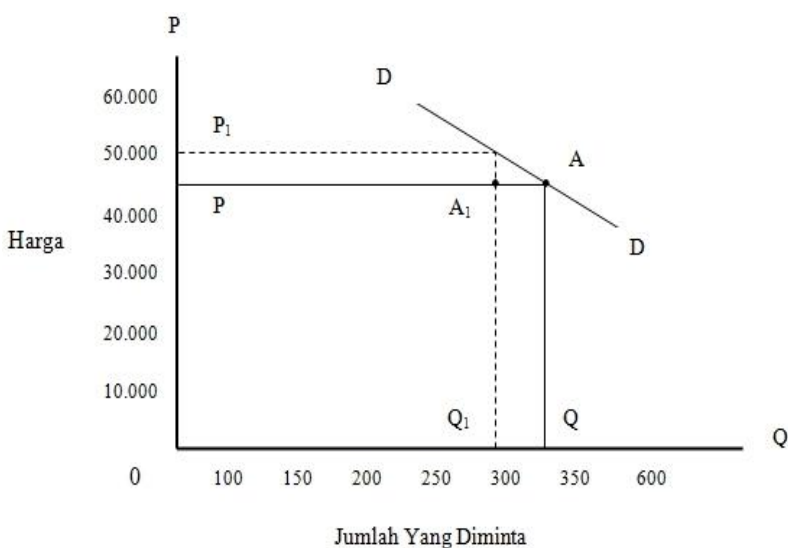

Gambar 3. Jumlah permintaan keripik ubi $\left(\mathrm{Q}-\mathrm{Q}_{1}\right)$ dan perubahan harga $\left(\mathrm{P}-\mathrm{P}_{1}\right)$ selama bulan Maret dan bulan April

Dapat dilihat bahwa mula-mula ekuilibirium berada pada titik A pada keadaan keseimbangan tersebut diatas, dengan harga pada bulan Maret adalah Rp.45.000/kg dan jumlah permintaan sebesar $339 \mathrm{~kg}$ karena pada bulan April harga penjualan keripik naik menjadi Rp.50.000/kg atau kenaikan harga sebesar $11 \%$ dengan akibat penurunan jumlah yang diminta sebesar $298 \mathrm{~kg}$ atau jumlah yang diminta sebesar 12\% ketitik $\mathrm{A}_{1}$ berarti elastisitas permintaan atas keripik ubi $\mathrm{E}_{\mathrm{d}}=$ $12 / 11=1,09 \%$. Dari perhitungan tersebut dapat disimpulkan permintaan keripik ubi ini bersipat elastis sepanjang kurva $\mathrm{A}$ ke $\mathrm{A}_{1}$, semakin tinggi kenaikan harga maka semakin rendah permintaan, sesuai dengan hukum permintaan. Dikarenakan keripik ubi hanya memiliki 1 (satu) jenis rasa yaitu rasa pedas, tidak mempunyai pilihan dalam membeli keripik ubi seingga konsumen beralih mengkonsumsi jenis keripik lain.

Hasil penilitian menunjukan permintaan jenis produk keripik Rempeyek dan pisang terhadap harga yang berubah bersifat in elastis atau $\left(E_{d}<1\right)$ dan jenis keripik ubi terhadap harga yang berubah bersifat elastis. Artinya pada saat harga naik konsumen mengurangi jumlah konsumsi keripik rempeyek, pisang dan keripik ubi. Itu terjadi karena bagi masyarakat di Kecamatan Baturaja Timur keripik merupakan kebutuhan barang yang bersifat normal menurut pendapatan konsumen, Barang normal yaitu barang yang permintaannya akan meningkat apabila pendapatan konsumen naik dan jumlah kebutuhannya sebagai cemilan atau sebagai makanan ringan. Pengaruh berkurangnya permintaan konsumen keripik disebabkan oleh beberapa faktor yaitu tersedianya barang pengganti apabila terjadi kenaikan harga, selain itu faktor citra rasa atau selera kosumen juga termasuk dalam pemilihan konsumen mengkonsumsi keripik apabila harga naik maka akan mengalihkan anggaran belanjanya untuk membeli bahan makanan lain, yang harganya lebih murah atau lebih pokok. 


\section{c. Nilai Elastisitas Permintaan Konsumen Pada Produk Terhadap Perubahan Harga Produk Lain.}

Perbedaan jenis produk keripik, menyebabkan perbedaan harga masing-masing jenis sehingga terjadi selisih permintaan keripik karena harga yang berbeda hal tersebut dapat ditunjukan pada Tabel 5. berikut:

Tabel 5. Data harga jual dan penjualan keripik pada Bulan Maret dan April 2017

\begin{tabular}{|c|c|c|c|c|c|c|}
\hline \multirow{2}{*}{$\begin{array}{l}\text { Jenis } \\
\text { keripik }\end{array}$} & \multicolumn{2}{|c|}{ Maret } & \multicolumn{2}{|c|}{ April } & \multicolumn{2}{|c|}{$\Delta$} \\
\hline & $\begin{array}{c}\text { Harga } \\
\text { (Kg/R } \\
\text { p/Bln) }\end{array}$ & $\begin{array}{l}\text { Permi } \\
\text { ntaan } \\
(\mathrm{Kg} / \mathrm{R} \\
\text { p/Bln) }\end{array}$ & $\begin{array}{c}\text { Harga } \\
\text { (Kg/R } \\
\text { p/Bln) }\end{array}$ & $\begin{array}{l}\text { Permi } \\
\text { ntaan } \\
(\mathrm{Kg} / \mathrm{R} \\
\text { p/Bln }) \\
\end{array}$ & $\begin{array}{l}\text { Harga } \\
(\mathrm{Kg} / \mathrm{R} \\
\text { p/Bln) }\end{array}$ & $\begin{array}{l}\text { Permi } \\
\text { ntaan } \\
(\mathrm{Kg} / \mathrm{R} \\
\text { p/Bln) }\end{array}$ \\
\hline $\begin{array}{l}\text { Peyek } \\
\text { (x) }\end{array}$ & 50.000 & 377 & 60.000 & 360 & 10.000 & 17 \\
\hline $\begin{array}{l}\text { Pisang } \\
\text { (y) }\end{array}$ & 45.000 & 345 & 50.000 & 317 & 5.000 & 28 \\
\hline $\begin{array}{l}\text { Ubi } \\
\text { (z) }\end{array}$ & 45.000 & 339 & 50.000 & 298 & 5.000 & 41 \\
\hline
\end{tabular}

Sumber : Analisi Data Primer 2015

Tabel diatas menunjukan selisih kenaikan harga dan perubahan permintaan terhadap keripik peyek sebesar Rp.10.000 dan 17 Kg. sedangkan untuk keripik pisang selisih kenaikan harganya pada bulan Maret dan April sebesar Rp.5.000 dan perubahan permintaannya sebesar $28 \mathrm{Kg}$. dan selisih kenaikan harga keripik ubi pada bulan Maret sampai dengan April Rp.5000 sedangkan perubahan permintaannya sebesar $41 \mathrm{Kg}$.

Perubahan atau perbedaan harga yang disebabkan oleh kenaikan bahan baku pembuatan keripik yang di akibat kan oleh kenaikan harga BBM yang tidak setabil sehingga produsen harus menaikan harga jual keripik pada bulan Maret dan April fenomena ini mempengaruhi permintaan konsumen sehingga terjadi subtitusi barang terhadap produk keripik lainnya di lima toko yang ada di Kecamatan Baturaja Timur, untuk lebih jelasnya dapat dilihat pada Tabel 9. berikut:

Tabel 6. Perhitungan Elastisitas Permintaan Konsumen Keripik Terhadap Permintaan Konsumen Dengan Harga Produk Lain Yang Berubah Pada Bulan Maret 2017

\begin{tabular}{|c|c|c|c|c|c|c|}
\hline $\begin{array}{c}\text { Jenis } \\
\text { Keripik }\end{array}$ & $\begin{array}{c}\text { Jenis } \\
\text { Keripik } \\
\text { Pengga } \\
\text { nti } \\
\end{array}$ & $\begin{array}{c}\Delta \text { Harga } \\
(\mathrm{Kg} / \mathrm{Rp} / \mathrm{B} \\
\ln )\end{array}$ & $\begin{array}{c}\Delta \text { Perminta } \\
\text { an } \\
(\mathrm{Kg} / \mathbf{R p} / \mathbf{B l} \\
\text { n) }\end{array}$ & $\begin{array}{c}\text { Harga } \\
(\mathrm{Rp} / \mathrm{Kg} / \mathrm{B} \\
\text { In) }\end{array}$ & $\begin{array}{c}\text { Perminta } \\
\text { an } \\
(\mathrm{Rp} / \mathrm{Kg} / \mathrm{B} \\
\text { ln })\end{array}$ & $\begin{array}{c}\text { Elastisitas } \\
(\mathbf{R p} / \mathrm{Kg} / \mathrm{B} \\
\text { ln) }\end{array}$ \\
\hline \multirow{4}{*}{$\begin{array}{c}\text { Rempey } \\
\text { ek }\end{array}$} & & & 17 & & 377 & $0,40 \%$ \\
\hline & Pisang & 5.000 & & 45.000 & & (in elastis) \\
\hline & & & 17 & & 377 & $0,40 \%$ \\
\hline & Ubi & 5.000 & & 45.000 & & (in elastis) \\
\hline \multirow{4}{*}{ Pisang } & & & 28 & & 345 & $0,40 \%$ \\
\hline & $\begin{array}{l}\text { Rempey } \\
\text { ek }\end{array}$ & 10.000 & & 50.000 & & (in elastis) \\
\hline & & & 28 & & 345 & $0,73 \%$ \\
\hline & Ubi & 5.000 & & 45.000 & & (in elastis) \\
\hline \multirow{4}{*}{ Ubi } & & & 41 & & 339 & $0.60 \%$ \\
\hline & $\begin{array}{l}\text { Rempey } \\
\text { ek }\end{array}$ & 10.000 & & 50.000 & & (in elastis) \\
\hline & & & 41 & & 339 & $1,08 \%$ \\
\hline & Pisang & 5.000 & & 45.000 & & (elastis) \\
\hline
\end{tabular}

Sumber : Analisi Data Primer 2017
Dari Tabel 6. diatas semua jenis keripik memiliki elastisitas permintaan terhadap produk lain dapat dijelaskan sebagai berikut:

\section{Keripik Rempeyek - Keripik Pisang}

Untuk menghitung elastisitas silang dari keripik Rempeyek terhadap Pisang menggunakan rumus sebagai berikut:

$$
\begin{array}{r}
\mathrm{E}_{\mathrm{q}} \mathrm{x}=\frac{\Delta \mathrm{Q}_{\mathrm{x}}}{\Delta \mathrm{P}_{\mathrm{y}}} \cdot \frac{\mathrm{P}_{\mathrm{y}}}{\mathrm{Q}_{\mathrm{x}}} \\
\mathrm{E}_{\mathrm{q}} \mathrm{x}=\frac{17}{5.000} \cdot \frac{45.000}{377} \\
\mathrm{E}_{\mathrm{q}} \mathrm{x}=0.0034 \mathrm{x} 119.36=0.40 \%
\end{array}
$$

Dari hasil perhitungan menunjukkan bahwa $\mathrm{E}_{\mathrm{p}} \mathrm{y}=$ $0,40>0$ berarti antara Keripik Rempeyek dan Keripik Pisang merupakan barang substitusi, yaitu bila harga beli per kg Keripik Rempeyek mengalami kenaikan, maka jumlah Keripik Rempeyek yang diminta akan turun dan peristiwa ini diikuti peningkatan jumlah Keripik Pisang yang diminta pasar namun peningkatan tersebut hanya di iringi sebesar 0,40\% saja. Sebaliknya jika harga beli per kg Keripik Rempeyek turun, jumlah Keripik Rempeyek yang diminta akan meningkat, sementara jumlah Keripik Pisang yang diminta mengalami penurunan.

\section{Keripik Peyek - Keripik Ubi}

Untuk menghitung elastisitas silang dari Keripik Rempeyek terhadap Ubi menggunakan rumus sebagai berikut:

$\mathrm{E}_{\mathrm{q}} \mathrm{x}=\frac{\Delta \mathrm{Q}_{\mathrm{x}}}{\Delta \mathrm{P}_{\mathrm{z}}} \cdot \frac{\mathrm{P}_{\mathrm{z}}}{\mathrm{Q}_{\mathrm{x}}}$

$\mathrm{E}_{\mathrm{q}} \mathrm{x}=\frac{17}{5.000} \cdot \frac{45.000}{377}$

$\mathrm{E}_{\mathrm{q}} \mathrm{x}=0.0034 \times 119.36=0.40 \%$

Dari hasil perhitungan sama dengan perhitungan sebelumnya menunjukkan bahwa $\mathrm{E}_{\mathrm{q}} \mathrm{x}=0,40>0$ berarti antara keripik Rempeyek dan keripik Ubi merupakan barang substitusi, yaitu bila harga beli per kg keripik Rempeyek mengalami kenaikan, maka jumlah keripik Rempeyek yang diminta akan turun dan peristiwa ini diikuti peningkatan jumlah keripik Ubi yang diminta pasar namun peningkatan tersebut hanya di iringi sebesar $0,40 \%$ saja. Sebaliknya jika harga beli per $\mathrm{kg}$ keripik Rempeyek turun, jumlah keripik Rempeyek yang diminta akan meningkat, sementara jumlah keripik Ubi yang diminta mengalami penurunan sebesar $0,40 \%$ juga. 


\section{Keripik Pisang - Keripik Rempeyek}

Untuk menghitung elastisitas silang dari Keripik Pisang terhadap Rempeyek menggunakan rumus sebagai berikut:

$$
\begin{gathered}
\mathrm{E}_{\mathrm{q}} \mathrm{y}=\frac{\Delta \mathrm{Q}_{\mathrm{y}}}{\Delta \mathrm{P}_{\mathrm{x}}} \cdot \frac{\mathrm{P}_{\mathrm{x}}}{\mathrm{Q}_{\mathrm{y}}} \\
\mathrm{E}_{\mathrm{q}} \mathrm{y}=\frac{28}{10.000} \cdot \frac{50.000}{345} \\
\mathrm{E}_{\mathrm{q}} \mathrm{y}=0.0028 \times 144,92=0.40 \%
\end{gathered}
$$

Dari hasil perhitungan di atas sama dengan perhitungan sebelumnya menunjukkan bahwa $\mathrm{E}_{\mathrm{q}} \mathrm{y}=$ $0,40>0$ berarti antara keripik Pisang dan keripik Rempeyek merupakan barang substitusi, yaitu bila harga beli per kg keripik Pisang mengalami kenaikan, maka jumlah keripik Pisang yang diminta akan turun dan peristiwa ini diikuti peningkatan jumlah keripik Rempeyek yang diminta pasar namun peningkatan tersebut hanya di iringi sebesar 0,40\% saja. Sebaliknya jika harga beli per kg keripik Pisang turun, jumlah keripik Pisang yang diminta akan meningkat, sementara jumlah keripik Rempeyek yang diminta mengalami penurunan sebesar $0,40 \%$ juga.

\section{Keripik Pisang - Keripik Ubi}

Untuk mendapatkan elastisitas silang dari Keripik Pisang terhadap Ubi menggunakan rumus sebagai berikut:

$$
\begin{gathered}
\mathrm{E}_{\mathrm{q}} \mathrm{y}=\frac{\Delta \mathrm{Q}_{\mathrm{y}}}{\Delta \mathrm{P}_{\mathrm{z}}} \cdot \frac{\mathrm{P}_{\mathrm{z}}}{\mathrm{Q}_{\mathrm{y}}} \\
\mathrm{E}_{\mathrm{q}} \mathrm{y}=\frac{28}{5.000} \cdot \frac{45.000}{345} \\
\mathrm{E}_{\mathrm{q}} \mathrm{y}=0.0056 \times 130,43=0.73 \%
\end{gathered}
$$

Dari hasil perhitungan sedikit berbeda dengan perhitungan sebelumnya menunjukkan bahwa $\mathrm{E}_{\mathrm{q}} \mathrm{y}=$ $0,73>0$ berarti antara keripik Pisang dan keripik Ubi merupakan barang substitusi, yaitu bila harga beli per kg keripik Pisang mengalami kenaikan, maka jumlah keripik Pisang yang diminta akan turun dan peristiwa ini diikuti peningkatan jumlah keripik Ubi yang diminta pasar namun peningkatan tersebut hanya di iringi sebesar $0,73 \%$ saja. Sebaliknya jika harga beli per kg keripik Pisang turun, jumlah keripik Pisang yang diminta akan meningkat, sementara jumlah keripik Ubi yang diminta mengalami penurunan sebesar $0,730 \%$ juga.

\section{Keripik Ubi - Keripik Rempeyek}

Untuk menghitung elastisitas silang dari Keripik Ubi terhadap Peyek menggunakan rumus sebagai berikut:

$$
\begin{aligned}
& \mathrm{E}_{\mathrm{q}} \mathrm{z}=\frac{\Delta \mathrm{Q}_{\mathrm{z}}}{\Delta \mathrm{P}_{\mathrm{x}}} \cdot \frac{\mathrm{P}_{\mathrm{x}}}{\mathrm{Q}_{z}} \\
& \mathrm{E}_{\mathrm{q}} \mathrm{z}=\frac{41}{10.000} \cdot \frac{50.000}{339} \\
& \mathrm{E}_{\mathrm{q}} \mathrm{z}=0.0041 \times 147,49=0.60 \%
\end{aligned}
$$

Dari hasil perhitungan di atas menunjukkan bahwa $\mathrm{E}_{\mathrm{q}} \mathrm{z}=0$, Ubi $>0$ berarti antara keripik Ubi dan keripik Rempeyek merupakan barang substitusi, yaitu bila harga beli per $\mathrm{kg}$ keripik Ubi mengalami kenaikan, maka jumlah keripik Ubi yang diminta akan turun dan peristiwa ini diikuti peningkatan jumlah keripik Rempeyek yang diminta pasar namun peningkatan tersebut hanya di iringi sebesar $0,60 \%$ saja. Sebaliknya jika harga beli per kg keripik Ubi turun, jumlah keripik Ubi yang diminta akan meningkat, sementara jumlah keripik Rempeyek yang diminta mengalami penurunan sebesar $0,60 \%$ juga.

\section{Keripik Ubi - Keripik Pisang}

Untuk mendapatkan elastisitas silang dari Keripik Ubi terhadap Pisang menggunakan rumus sebagai berikut:

$$
\begin{array}{r}
\mathrm{E}_{\mathrm{q}} \mathrm{z}=\frac{\Delta \mathrm{Q}_{\mathrm{z}}}{\Delta \mathrm{P}_{\mathrm{y}}} \cdot \frac{\mathrm{P}_{\mathrm{y}}}{\mathrm{Q}_{\mathrm{z}}} \\
\mathrm{E}_{\mathrm{q}} \mathrm{z}=\frac{41}{5.000} \cdot \frac{45.000}{339} \\
\mathrm{E}_{\mathrm{q}} \mathrm{z}=0.0082 \times 132,74=1.08 \%
\end{array}
$$

Dari hasil perhitungan di atas sama dengan perhitungan sebelumnya menunjukkan bahwa $\mathrm{E}_{\mathrm{q}} \mathrm{z}=$ $1.08>0$ berarti antara Keripik Ubi dan Keripik Pisang merupakan barang substitusi, yaitu bila harga beli per $\mathrm{kg}$ Keripik Ubi mengalami kenaikan, maka jumlah Keripik Ubi yang diminta akan turun dan peristiwa ini diikuti peningkatan jumlah Keripik Pisang yang diminta pasar sebesar $1.80 \%$.

Hasil penelitian diatas menunjukan elastisitas permintaan terhadap berbagai jenis produk keripik lainnya. Semua jenis keripik tersebut memiliki sifat subtitusi yang hampir sama seperti yang dilihat pada penjelasan diatas semuanya bersifat subtitusi positif 
namun perbedaannya hanya jumlah persentase elastisitas silangnya, atau mempuyai sifat $\left(\mathrm{E}_{\mathrm{q}}>0\right)$. Di satu sisi jenis tertentu keripik ubi terhadap keripik pisang yang harganya sama namun elastisitas silangnya lebih tinggi yaitu sebesar $1.08 \%$. Artinya permintaan konsumen tidak terpengaruh oleh harga semata namun faktor lain seperti citarasa atau selera konsumen dalam mengkonsumsi keripik, oleh karna itu perlu di adaanya inovasi rasa untuk menjaga kesetabilan permintaan konsumen. Sehingga walau pun harga jual keripik meningkat permintaan konsumen mampu hanya turun sedikit dari permintaan sebelumnya.

\section{KESIMPULAN}

Berdasarkan hasil penelitian yang telah dilakukan, maka dapat disimpulkan sebagai berikut:

1. Elastisitas permintaan keripik terhadap perubahan harga berdasarkan hasil penelitian menunjukan bahwa :

- Elastisitas harga keripik peyek mengalami peningkatan sebesar $20 \%$ dan penurunan permintaan jumlah produk sebesar $4 \%$ sehingga elastisitas permintaan terhadap keripik peyek sebesar 0,22 dan.

- Elastisitas harga keripik pisang mengalami peningkatan sebesar $11 \%$ dan penurunan permintaan jumlah produk sebesar $8 \%$ sehingga elastisitasnya 0,73 . jadi respon permintaan konsumen terhadap kedua keripik ini tidak elastis (in elastis) namun

- Elastisitas harga keripik ubi mengalami peningkatan sebesar $11 \%$ dan penurunan permintaan jumlah produk sebesar $12 \%$ maka elastisitas permintaan terhadap keripik ubi sebesar $=1,09$. Sehingga respon permintaan konsumen bersifat elastis namun itu pun sifatnya tidak telalu banyak.

2. Elastisitas terhadap produk lain berdasarkan hasil penelitian menunjukan hasil sebagai berikut :

- Elastisitas silang terhadap Semua jenis keripik tersebut memiliki sifat subtitusi yang sama seperti yang dilihat pada penjelasan diatas hampir semuanya bersifat in elasatis, atau mempuyai sifat $\left(\mathrm{E}_{\mathrm{q}}<1\right)$.

- Di satu sisi jenis tertentu keripik ubi terhadap keripik pisang yang harganya sama namun elastisitas silangnya lebih tinggi yaitu sebesar $1.08 \%$.
- Hal diatas dapat terjadi dikarnakan produk jenis keripik ini bersifat kebutuhan normal di saat harga produk naik konsumen cendrung menurunkan konsumsinya terhadap makanan ringan, namun konsumen juga tidak serta merta menurunkan lebih konsumsinya itu dikarnakan oleh faktor citarasa atau selera maka jika harga keripik naik konsumen hanya menurunkan sedikit dari konsumsi sebelumnya.

\section{DAFTAR PUSTAKA}

Agustina Nina. 2015, Pemilik UKM "Cita Rasa" Kec. Baturaja Timur Kabupaten Ogan Komering Ulu, 2015. Tidak Di Publikasikan.

Andri. 2013. Analisis perilaku konsumen beras organik di Kabupaten Jember. J SEP Vol 5 No 3 November 2011.

Arjuna. 2015, Pemilik UKM “Arta” Kec. Baturaja Timur Kabupaten Ogan Komering Ulu, 2015. Tidak Di Publikasikan.

Dinas perindustrian dagangan koprasi UKM Kabupaten Ogan Komering Ulu 2013 Tidak Di Publikasikan.

Sriati. 2014. Metodologi Penelitian Ilmiah. Universitas Sriwijaya. Palembang

Suharto. 2015, Pemilik UKM "Harmoni" Kec. Baturaja Timur Kabupaten Ogan Komering Ulu, 2015. Tidak Di Publikasikan. 